\title{
Seismic stratigraphic analysis for hydrocarbon exploration in the Beta Field, Coastal Swamp Depobelt, Niger Delta
}

\author{
Mutiu Adesina Adeleye $e^{1}$, Kazeem Oladayo Yekeen², Sikiru Adetona Amidu ${ }^{3}$ \\ ${ }^{1}$ University of Ibadan, Department of Geology; Ibadan, Nigeria; \\ e-mail: mutiuadeleye@gmail.com; ORCID ID: 0000-0002-6915-3043 \\ ${ }^{2}$ University of Ibadan, Department of Geology; Ibadan, Nigeria; e-mail: kazeemyekeenoladayo@gmail.com \\ ${ }^{3}$ Mobil Producing Nigeria Unltd, I Lekki-Expressway; Victoria Island, Lagos, Nigeria; e-mail: aamidu001@yahoo.com
}

(C) 2020 Authors. This is an open access publication, which can be used, distributed and reproduced in any medium according to the Creative Commons CC-BY 4.0 License requiring that the original work has been properly cited.

Received: 16 February 2020; accepted: 8 December 2020; first published online: 22 December 2020

\begin{abstract}
Hydrocarbon exploration analysis from a seismic stratigraphic approach was carried out within the Beta Field, Coastal Swamp Depobelt, Niger Delta, to identify system tracts and sequence boundaries that could be associated with potential hydrocarbon accumulation. 3D seismic volume and data from four wells were analyzed. Depositional sequences, system tracts, sequence boundaries, and candidate maximum flooding surfaces were picked from logs, while reflection patterns and terminations were interpreted from seismic sections. Log shapes from gamma rays in combination with seismic facies analysis were interpreted in order to delineate lithology, depositional environments and depositional sequences. Seismic attributes were extracted and were draped on gridded surfaces from the interpreted seismic horizons. These were integrated with structure maps to obtain structural and stratigraphic trends, and possible presence of reservoir sand.

Five depositional sequences and nine seismic facies were identified within the field. The depositional sequences were designated Sequences S1 to S5 based on the depth of the occurrences and stacking patterns. This study reveals a progression from fluvial depositional settings to the shelf. The main reservoirs identified are the sand units of the highstand and lowstand within three depositional sequences (S1, S4 and S5) although interbedded sands within the TST of S4 and S5 are also suspected of being potential reservoirs. The channel sand deposits within the study area are suspected to be hydrocarbon bearing as they occurred within the complex fault trapping system popular in the Niger Delta. The application of seismic stratigraphy, as shown in this study, serves to encourage exploration in the Niger Delta where it could be effectively employed for reducing risk in hydrocarbon exploration.
\end{abstract}

Keywords: seismic stratigraphy, system tracts, sequence boundary, depositional sequences, reservoir presence, Nigeria

\section{INTRODUCTION}

Seismic stratigraphy uses seismic reflection patterns to identify depositional sequences to predict the lithology of seismic facies by interpreting depositional processes and environmental settings, and to analyze relative changes in sea level as recorded in the stratigraphic records. The use of seismic stratigraphy for identifying exploration targets has been the focus of several studies (e.g. Galloway 1975, Brown \& Fisher 1977, Mitchum et al. 1977, Payton 1977, Armentrout \& Perkins 1991, Miall 1991, Posamentier \& George 1994, Galloway 1998, Davies et al. 2004, Catuneanu 2006). These studies have shown that seismic stratigraphic principles can help to improve seismic interpretations. Stratigraphic interpretations, such as geologic time correlations, the definition of genetic 
depositional units, and thickness and depositional environment of genetic units can be achieved using seismic stratigraphy (Mitchum et al. 1977, Catuneanu 2006). Generally, application of seismic stratigraphic techniques has become an important component of standard seismic interpretation workflows. The method has continued to enhance the identification of drillwell opportunities with reduced risks and uncertainties in business decisions, especially where there are well controls. Also, as exploration continues to move into frontier regions and into deeper parts of sedimentary basins where well control is limited or lacking, fundamental to delineating drilling targets is interpreting stratigraphy, sedimentary facies, and geologic history from seismic reflection data (Galloway 1976, Cross \& Lessenger 1988, Paumard et al. 2019, Cawthra et al. 2020).

Seismic reflection profiles form an important source of data for the interpretation of subsurface stratigraphy and depositional systems. Veeken (2007) reported that four major groups of systematic reflections are distinguished on seismic sections: sedimentary reflections representing bedding planes; unconformities or discontinuities in the geological record; artefacts like diffractions and multiples; and non-sedimentary reflections like fault planes and fluid contacts. One of the standard operations in seismic interpretation for hydrocarbon exploration is the ability to identify and distinguish the various subsurface features that fall under these aforementioned categories from the seismic data. These features are subsequently evaluated for their possible implications for hydrocarbon accumulations, if any, in the area of interest. Generally, to delineate geological features and potential areas of commercial oil and gas accumulations, the seismic reflection data must be interpreted in a geological meaningful manner using various interpretation techniques, one of which is seismic stratigraphy.

Recent advances in seismic acquisition, processing and interpretation technologies have made seismic reflection data increasingly available to illustrate the subsurface. In particular, with advances in software and interpretation technologies, three-dimensional seismic data can be routinely integrated with well data to generate various technical products from the seismic data. Examples of such technical products include: seismic horizons, seismic attribute extractions, horizon probes, frequency and phase data, geobodies, and others. When integrated with stratigraphic analyses, these technical products can yield insights regarding the distribution of source, seal, and reservoir rocks.

The Niger Delta Basin is ranked among the highest hydrocarbon producing basins in the world, with several reserves that are yet to be discovered as exploration advances into deeper waters (Ekweozor et al. 1984, Slatt 2013). The lithostratigraphic subdivision of the Niger Delta sediments cut across time lines and their lateral associations suggested that the sedimentary deposits were strongly influenced by eustasy and tectonics (Doust \& Omatsola 1990). There is a close relationship between and structure and stratigraphy of the Niger Delta, and they showed the interplay of sediment supply and subsidence rates (Doust 1990). As reported by Ekweozor \& Daukoru (1994), the primary source rock is the Akata Formation, which is the marine-shale facies of the delta. In addition, there is a possible contribution made from the interbedded marine shale of the lowermost Agbada Formation (Ekweozor \& Daukoru 1994). Oil is produced from sandstone facies within the overlying Agbada Formation, however, turbidite sand in the Akata Formation is a potential target in deep water offshore and possibly beneath currently producing intervals onshore (Ekweozor et al. 1979, Doust 1990).

The Niger Delta is located at the apex of the Gulf of Guinea (Fig. 1) on the West African continental margin, which formed the site of a triple junction during continental break-up in the Cretaceous. The sedimentary basin occupies a total area of about $75,000 \mathrm{~km}^{2}$ and its deepest part is about $11 \mathrm{~km}$. Throughout its history, the delta has been fed by the Niger, Benue and Cross rivers, which between them drain more than $106 \mathrm{~km}^{2}$ of continental lowland savannah (Doust 1990). The study location (Lat $6^{\circ} 6^{\prime} 00^{\prime \prime}$ to $7^{\circ} 24^{\prime} 00^{\prime \prime}$ and Long $4^{\circ} 23^{\prime} 60^{\prime \prime}$ to $4^{\circ} 30^{\prime} 40^{\prime \prime}$ ) covers approximately $19.7 \mathrm{~km}^{2}$ within the coastal swamp depobelt in the southern part of the Niger Delta.

Further exploration and accurate identification of the petroleum system of any hydrocarbon field has become very important due to diminishing conventional petroleum resources, thereby 
making exploration and production companies keen to produce and develop smaller and more complex reserves. Seismic stratigraphy has proven to be a highly successful tool in the exploration and production of petroleum resources within these smaller and complex reserves. The aim of this study is to identify system tracts using the seismic stratigraphic concept in the Beta Field within the Niger Delta, and to optimally map sequence boundaries that are associated with potential hydrocarbon accumulation in order to reduce overall exploration risk.

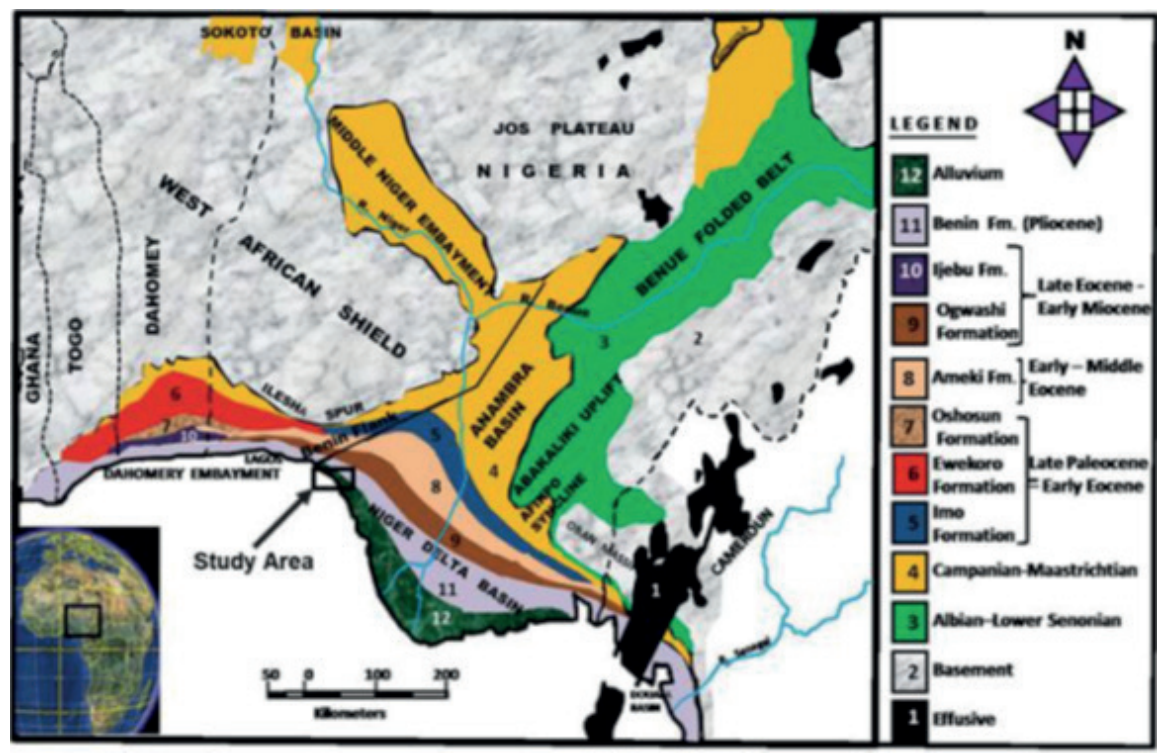

Fig. 1. Geological map of Nigeria showing the location of the study area (Niger Delta) (modified after Murat 1972)

\section{MATERIALS AND METHODS}

Well logs comprising of caliper, self-potential (SP), gamma ray (GR), sonic, density, and resistivity logs from four wells, 3D seismic data, and check shot data were utilized for this study. The research design focuses on the integration of seismic and well data in stratigraphic interpretations for hydrocarbon exploration and the identification of drillwell opportunities within the Beta Field in the southern part of the Niger Delta. Schlumberger Petrel software was used for the seismic interpretation and stratigraphic facies analyses. Figure 2 shows the base map with seismic survey outline and existing wells in the study area. The in-lines and cross-lines oriented NS and EW respectively are also shown on the map. A flowchart (Fig. 3) of the five project set up displays the methods used from data quality checks, seismic facies and hydrocarbon play analyses, as well as the environment of deposition (EOD).

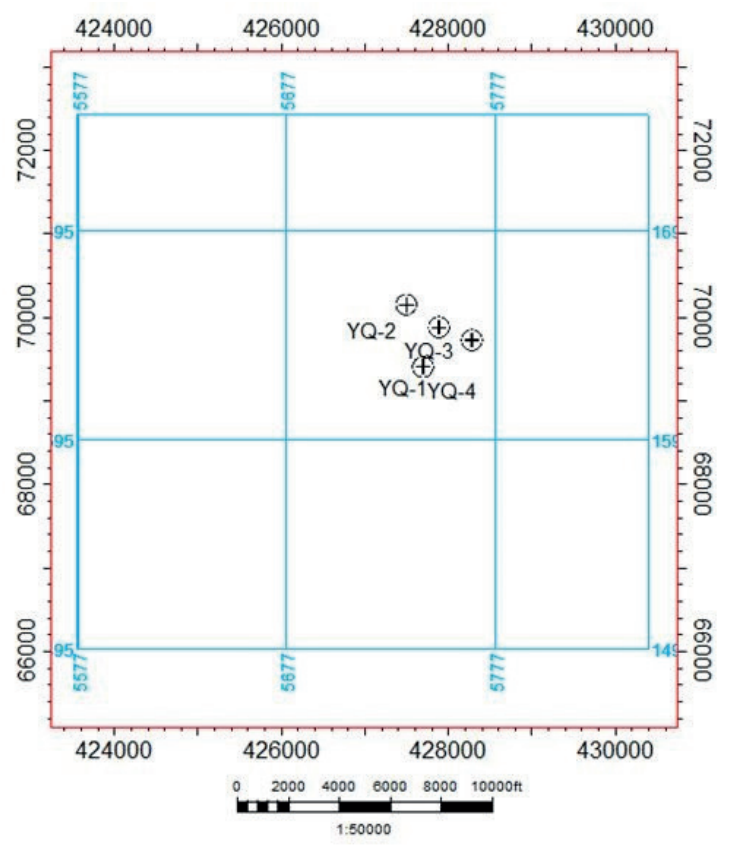

Fig. 2. Base map of the study area 


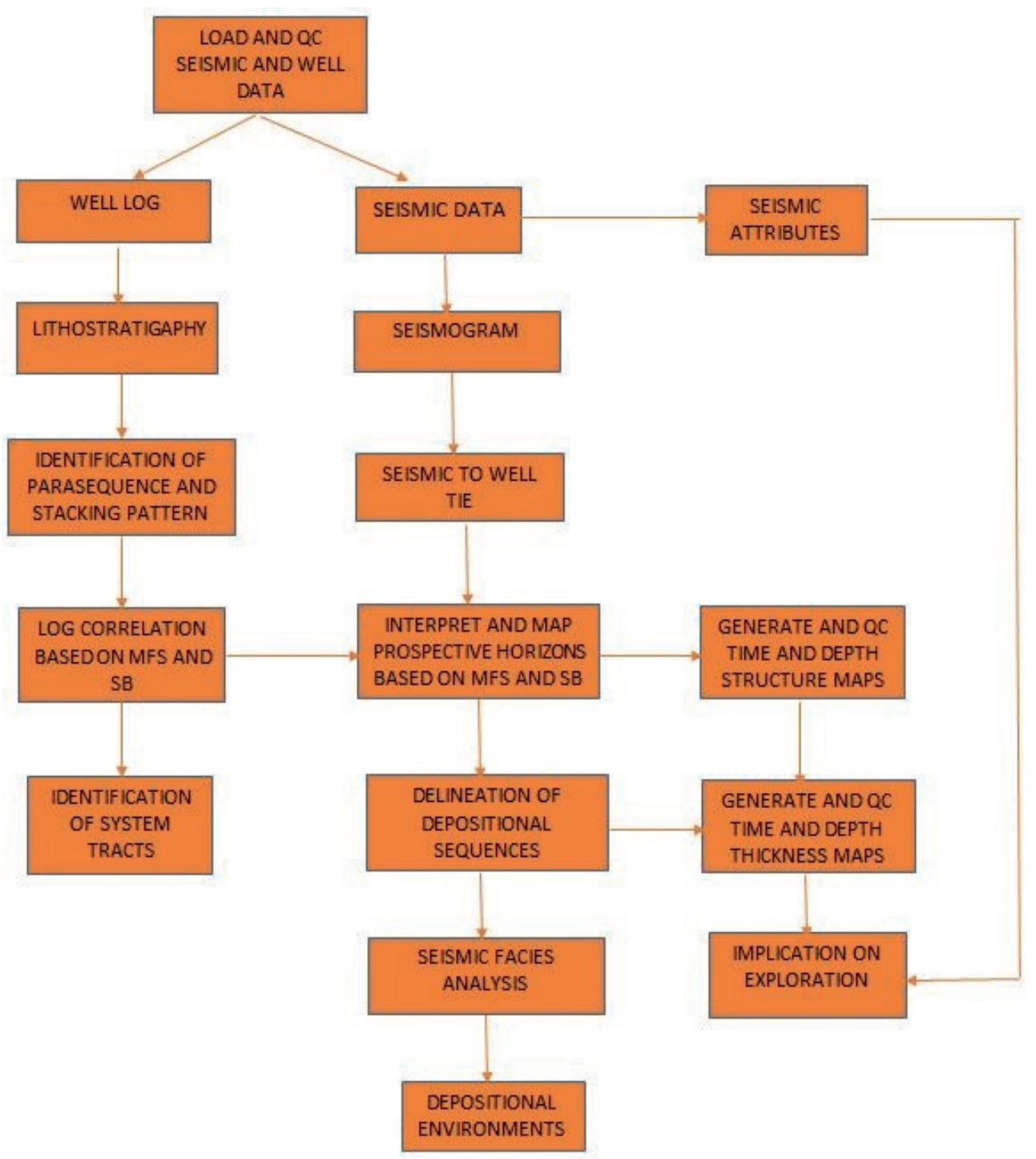

Fig. 3. Methodology flowchart

\section{Well logs and seismic data interpretation}

The gamma ray log provides a measure of sediment type with curve deflection to the right indicating an increase in clay content. Maximum flooding surfaces have been interpreted from the gamma ray $\log$ as spikes to the right are often associated with uranium concentrations in condensed sections. Well log shapes were interpreted as predicting lithology, lithofacies, depositional environment and depositional sequence. Well correlation was done to determine the lateral continuity of facies, thereby aiding reservoir studies. Identification of reservoirs was carried out using the gamma ray and resistivity logs. The reservoir zones were delineated by the deflection of the gamma ray $\log$ to the left (lower gamma API value), depicting porous sand units, and the deflection of the resistivity log to the right, indicating the presence of a resistive hydrocarbon fluid within the same interval.

The seismic data analysis was done following the procedures of Van Wagoner et al. (1988). This procedure consists of a data quality check, well correlation, synthetic seismogram generation, selection and interpretation of seismic reflectors, horizons picking using well log guidance, seismic attribute extraction and analysis, 
seismic sequence analysis, and data integration. Well correlation was carried out to map sequence boundaries, transgressive surfaces, and maximum flooding surfaces. These surfaces were identified based on the abrupt change in well log properties (gamma ray, resistivity and density, among others). The following steps were taken in order to correlate maximum flooding surfaces across the field on well logs:

1. Points of highest gamma ray value and lowest shale resistivity values were picked as maximum flooding surfaces.

2. Maximum flooding surfaces were correlated in all wells within a background of parasequence and parasequence sets stacking pattern (Van Wagoner et al. 1990, Posamentier \& George 1994).

The synthetic seismograms were generated from seismic well tie analyses using checkshot and sonic logs from the wells. This was followed by structural and stratigraphic mapping. Horizons were picked using well tops guidance. The time surfaces were generated and converted into depth structure maps after the completion of the seismic interpretation.

\section{Seismic stratigraphic analysis}

Seismic sequence analysis defines the genetic reflection packages referred to as seismic sequences and seismic system tracts by identifying discontinuities on the basis of reflection termination patterns. Depositional sequences, system tracts, system boundaries and candidate maximum flooding surfaces (MFS) were identified based on their diagnostic characteristic log patterns in the study area. Sequence boundaries (SB) were recognized from logs, and reflection patterns and terminations from the seismic section. Seismic facies analysis was carried out based on reflection configurations, continuity, amplitude (by employing facies related attribute), frequency (employing facies related attributes), and the exterior form of the reflection packages (Mitchum et al. 1977, Ramsayer 1979, Snedden \& Sarg 2008).

\section{System tracts}

The system tracts were identified by studying gamma ray logs and resisitivity logs from the wells. The highstand system tracts (HST) which are characterized by aggradational to progradational parasequence set, were overlain by a sequence boundary and underlain by maximum flodding surface. The lowstand system tract (LST) overlain by transgressive surface and underlain by a sequence boundary is characterized by a progradational to aggradational parasequence set. The transgressive system tract (TST) characterized by retrogradational parasequence set is overlain by a maximum flooding surface and underlain by a transgressive surface (TS).

\section{Seismic attribute analysis}

Root Mean Square (RMS) attributes of the seismic volume was obtained and the extraction of attributes using the interpreted surfaces was carried out to delineate stratigraphic trends, and channel reservoir sands and geometries. The use of RMS for surface attribute analysis was done to predict vertical and horizontal variations in relative acoustic impedance over the study area. It was observed that the higher the relative acoustic impedance variation of stacked lithology (with bed thicknesses above the seismic resolution), the higher the RMS values. Finally, using the relevant interpretation modules and integration platforms in Petrel, the integration of attribute extractions, time and depth structure maps were used to identify reservoirs and seal rocks, as well as potential trapping mechanisms for the reservoir rocks.

\section{RESULTS}

\section{Lithostratigraphy}

Generally, the lithology interpreted from the detailed observation of gamma ray log signatures shows the vertical alternation of sand and shale. The interpreted sand-shale lithologies from gamma ray logs of the Beta Field are shown in Figure 4 . The upper part of the sequences across wells in the study area display thicker sand intervals than shale and a coarsening upward trend, while the shale thickness increases relatively to sand interval at the lower part of the wells. The lithology (Fig. 4) is dominated by alternating sand and shale occurring approximately in a 65:35 ratios within the logged intervals. 
FiveSBwereidentified in thewellsYQ-1 and YQ-2; one SB in Well YQ-3, and two SB in Well YQ-4. Five MFS were also identified across the wells in the field with exception in wells YQ-3 and YQ-4 where one MFS was each identified (Fig. 5). The results of the seismic well tie using the well YQ-1 is presented in Figure 6. It was generally observed that good seismic to well ties were achieved for the four wells. A display of gamma ray log on a vertical seismic section through the well after seismic well tie is shown in Figure 7. Sequel to completion of seismic well tie, the interpreted sequence boundaries integrating well tops and stacking patterns from well logs are shown in Figure 8.

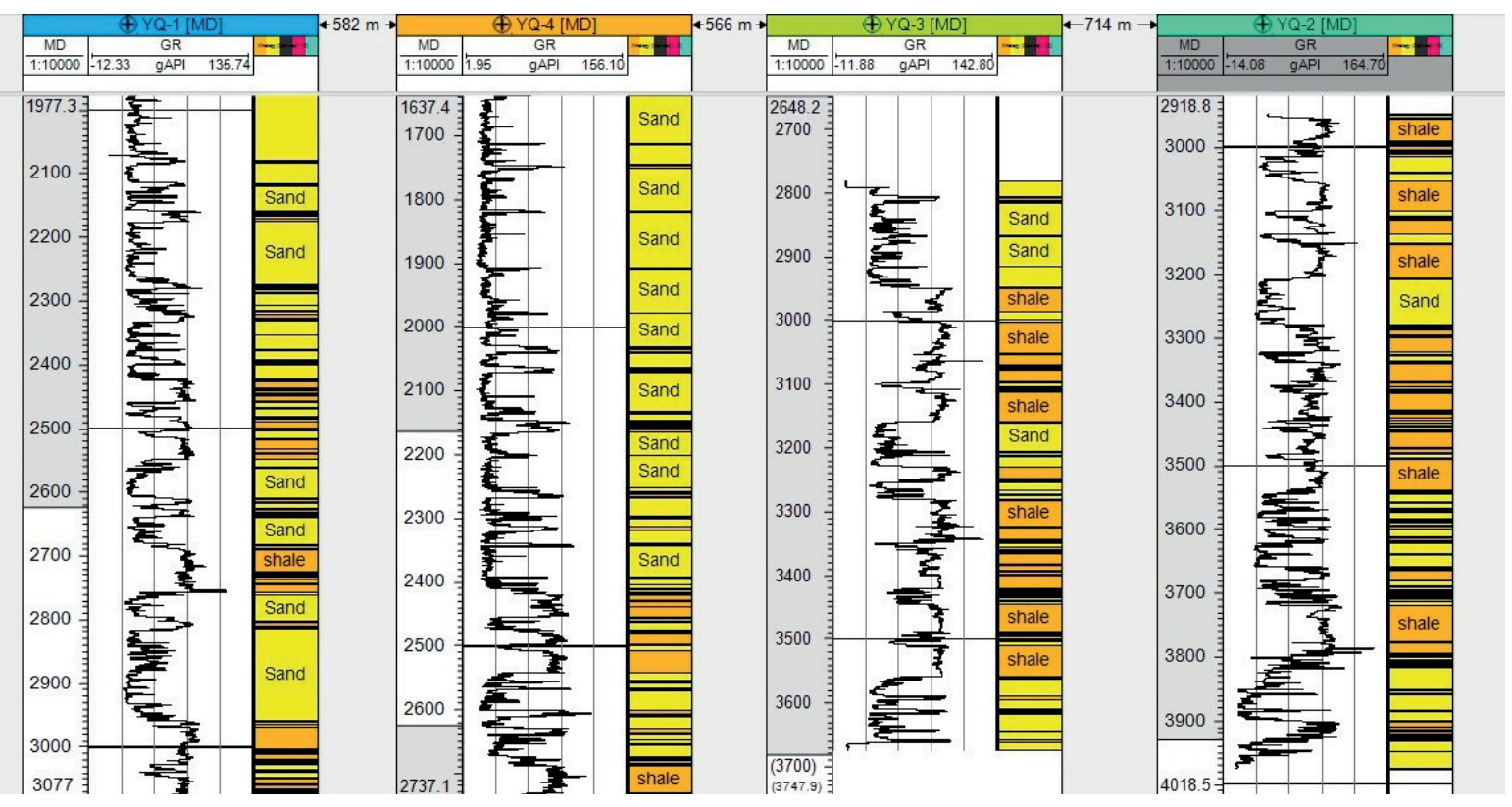

Fig. 4. Sand/shale lithologies within Beta Field

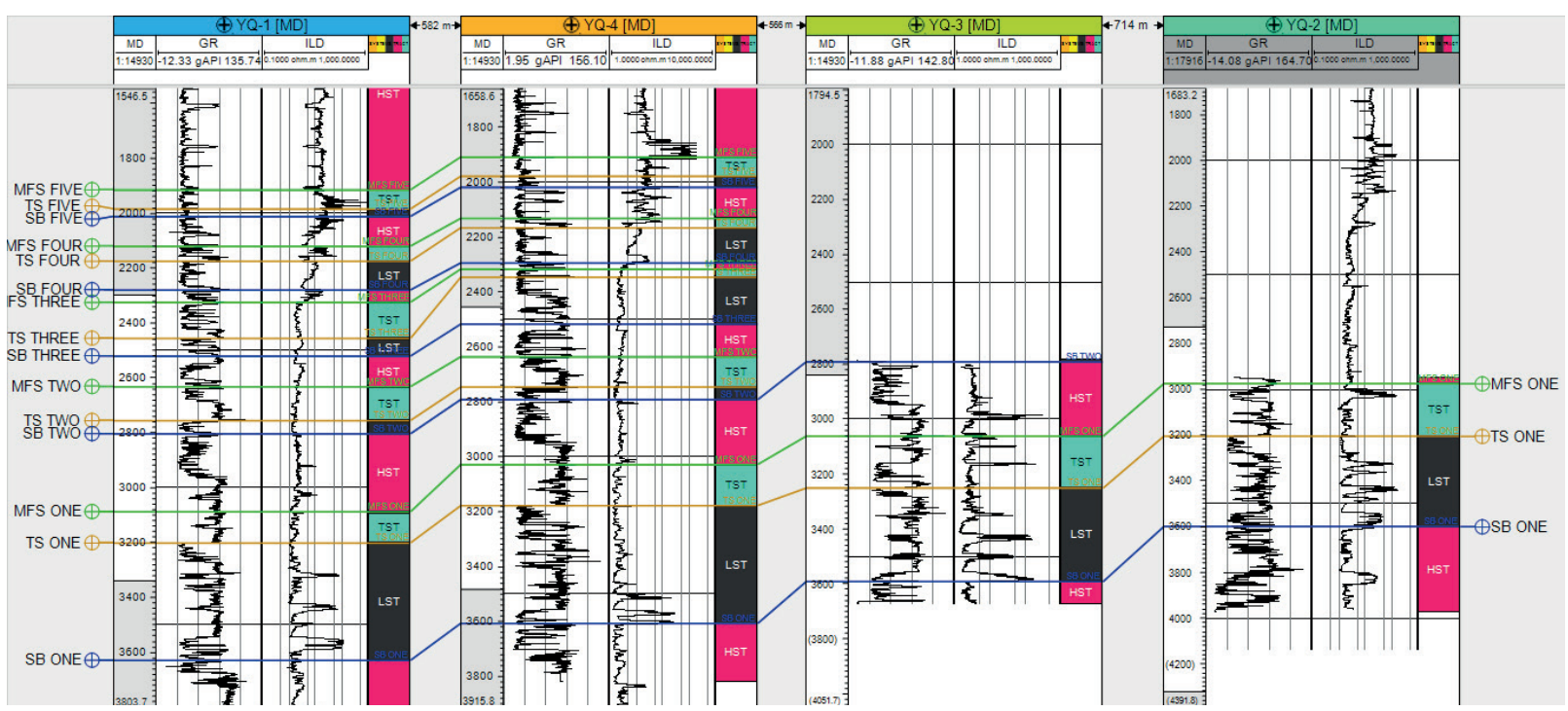

Fig. 5. Stratigraphic correlation of 4 wells in the studied field 


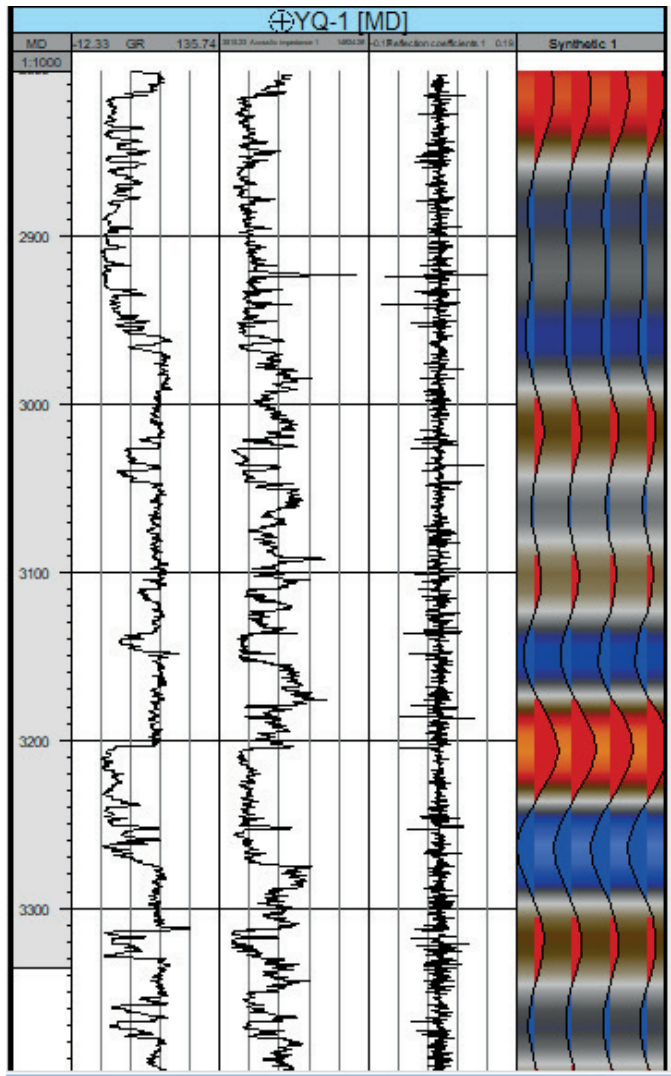

Fig. 6. Seismic to well tie showing synthetic seismogram

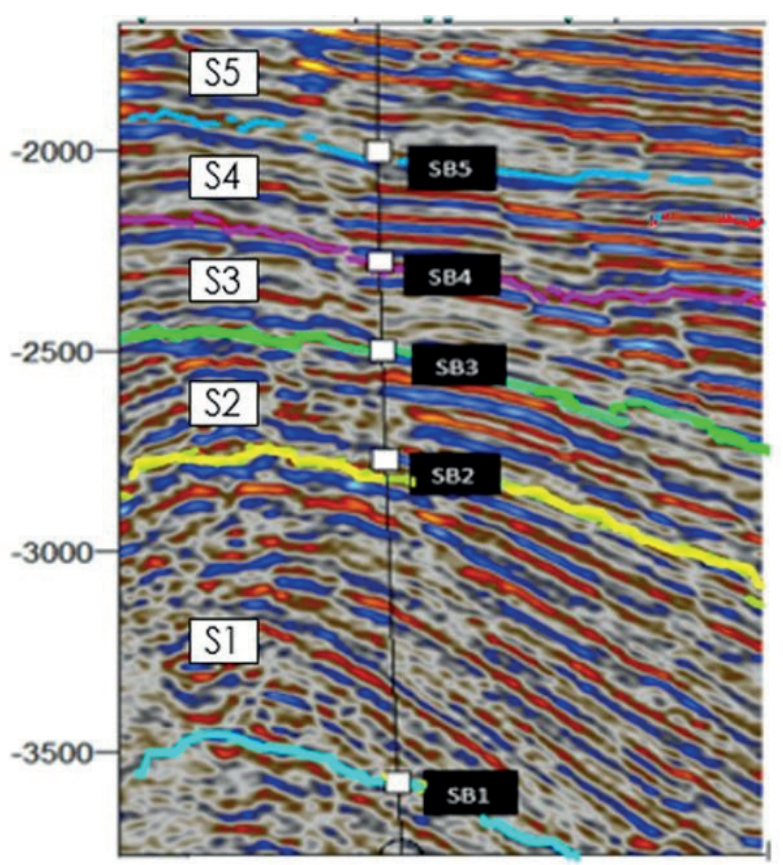

Fig. 8. Seismic to well tie showing the sequence boundaries

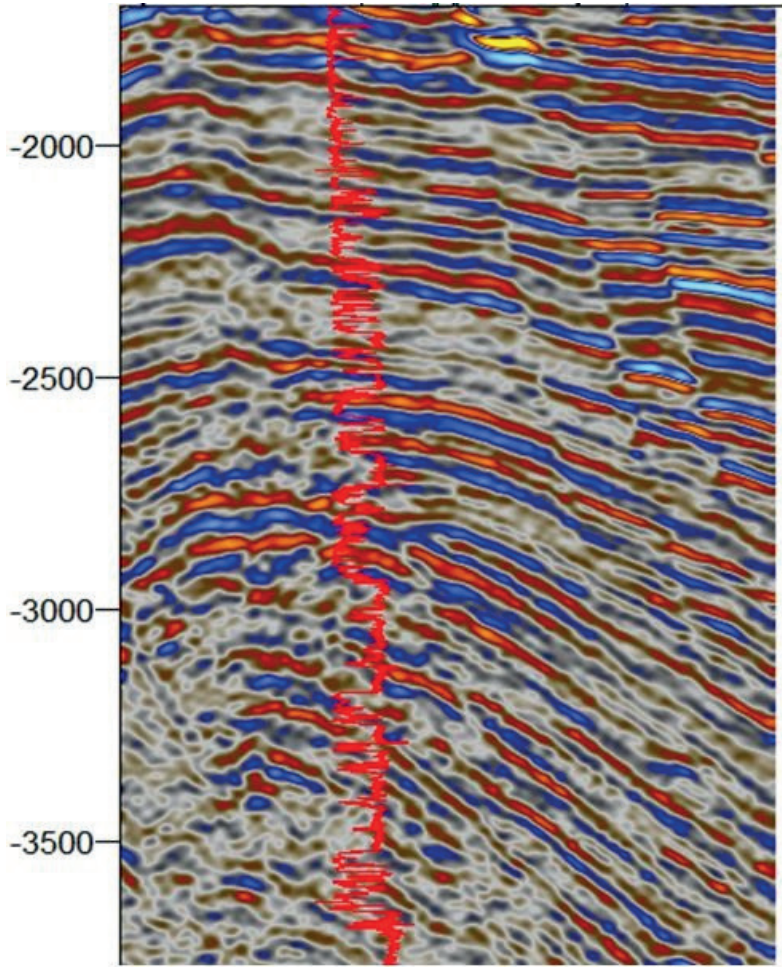

Fig. 7. Seismic to well tie with overlay of gamma ray log from well YQ-1

\section{Structural analysis and mapping}

Examples of major faults that were interpreted as subvertical discontinuities in the seismic data are shown in Figure 9. Multiple faulting which resulted in series of subsidence and sedimentation affected the Beta Field in the offshore depobelt. It was anticipated that sediments supplied would have been accommodated in the space created by the subsidence initiated by faults. The downthrown fault blocks have thicker sediments accumulation compared to their up-thrown fault blocks. Most of the faults mapped within the field which were picked on the seismic sections were along the dip.

\section{Seismic facies}

Nine seismic facies were identified within the study area (Fig. 10). These facies were analyzed based on reflection configurations, amplitude, and continuity, which aided a reasonable interpretation throughout the section. 


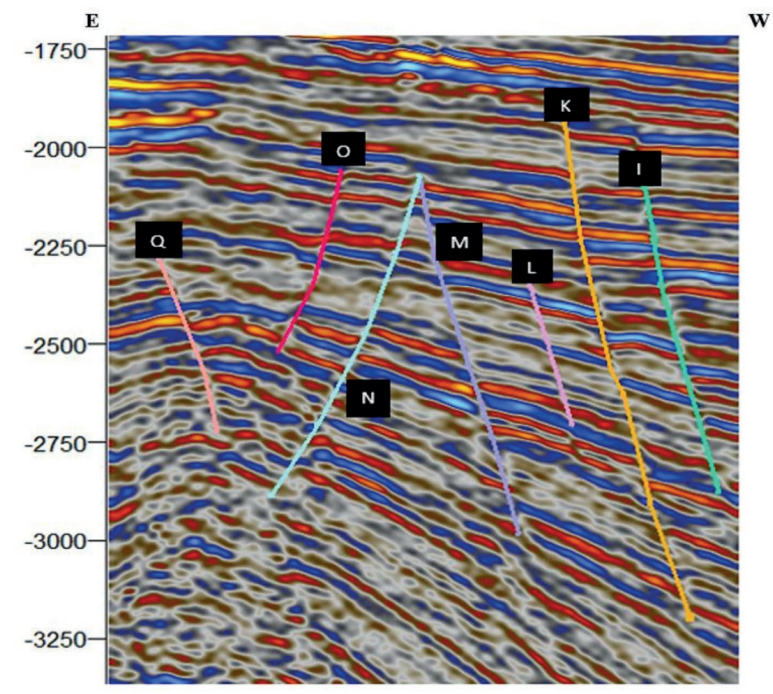

Fig. 9. Seismic section showing Inline 1595 with example of mapped Faults $I, K, L, M, N, O$, and Q, within Beta Field (in-lines) are synthetic faults with few antithetic faults

\begin{tabular}{|c|c|c|c|c|c|}
\hline Seismic Facies (SF) & Characteristics & Interpretation & Seismic Facies (SF) & Characteristics & Interpretations \\
\hline $\mathrm{SF} 1_{\mathrm{S}}$ & $\begin{array}{l}\text { Parallel, high } \\
\text { continuity, high } \\
\text { amplitude } \\
\text { reflection }\end{array}$ & $\begin{array}{l}\text { Shoreface } \\
\text { clastic } \\
\text { facies }\end{array}$ & 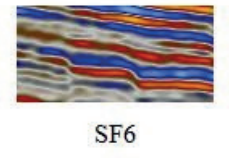 & $\begin{array}{l}\text { Complex simoid- } \\
\text { oblique, medium to high } \\
\text { amplitude, intermediate } \\
\text { internal reflection }\end{array}$ & $\begin{array}{l}\text { Deltaic or slope } \\
\text { channel fill } \\
\text { deposits }\end{array}$ \\
\hline$\sum_{\mathrm{SF} 2}$ & $\begin{array}{l}\text { Divergent, good } \\
\text { continuity, high } \\
\text { amplitude } \\
\text { reflection }\end{array}$ & $\begin{array}{l}\text { Marine } \\
\text { syntectonic } \\
\text { deposits }\end{array}$ & $\underset{\text { SF7 }}{203}$ & $\begin{array}{l}\text { Hummocky chiroform, } \\
\text { discontinuous, subparallel, } \\
\text { low to moderate amplitude, } \\
\text { nonsystematic termination }\end{array}$ & $\begin{array}{c}\text { Shallow marine } \\
\text { deposits }\end{array}$ \\
\hline$\frac{\sqrt{\mathrm{CN}}}{\mathrm{SF} 3}$ & $\begin{array}{l}\text { Subparallel to } \\
\text { parallel, good to } \\
\text { fair continuity, } \\
\text { high to medium } \\
\text { amplitude }\end{array}$ & $\begin{array}{l}\text { Medial fan } \\
\text { delta deposit }\end{array}$ & SF8 & $\begin{array}{l}\text { Mounded, moderate } \\
\text { to high amplitude }\end{array}$ & $\begin{array}{l}\text { Siliciclastic } \\
\text { buildups }\end{array}$ \\
\hline 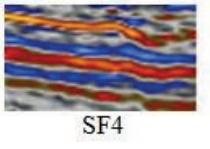 & $\begin{array}{l}\text { Sigmoid, medium to } \\
\text { high amplitude, } \\
\text { intermediate } \\
\text { frequency reflection }\end{array}$ & $\begin{array}{l}\text { Fan delta } \\
\text { deposits }\end{array}$ & 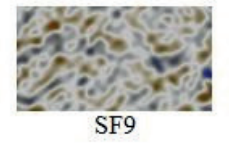 & $\begin{array}{l}\text { Chaotic, low to } \\
\text { moderate amplitude, } \\
\text { intermediate frequency }\end{array}$ & $\begin{array}{c}\text { Mass transport } \\
\text { deposits }\end{array}$ \\
\hline$\frac{\mathrm{SN}_{\mathrm{SF} 5}}{\mathrm{SN}}$ & $\begin{array}{l}\text { Oblique-tangential, } \\
\text { medium to high } \\
\text { amplitude, high to } \\
\text { intermediate } \\
\text { frequency reflections }\end{array}$ & $\begin{array}{l}\text { Shelfal } \\
\text { progradation } \\
\text { deposits }\end{array}$ & & & \\
\hline
\end{tabular}

Fig. 10. Identified seismic facies with interpretations from Beta Field

\section{Depositional sequences and the system tract}

Table 1 shows five depositional sequences that were interpreted in YQ-1 and YQ-2 wells. Correlation across the wells shows that sequences are not all represented in the wells. Sequences 2, 3, 4 , and 5 are not represented in YQ-3 and YQ-4 wells. An increase in thickness and subsequent decrease in thickness observed within a sequence implies changes in the accommodation space relative to sediment supply, beginning with high rates of accommodation and evolving into relatively low accommodation rates. 
Table 1

Summary of seismic stratigraphic interpretation

\begin{tabular}{|c|c|c|c|c|c|c|}
\hline Sequence(s) & Lithology & $\begin{array}{l}\text { Systems } \\
\text { tracts }\end{array}$ & $\begin{array}{c}\text { Gamma ray } \\
\text { log motif }\end{array}$ & Stacking pattern & $\begin{array}{c}\text { Type of chrono- } \\
\text {-surface }\end{array}$ & Remark \\
\hline \multirow{3}{*}{ S1 } & sand & HST & $\begin{array}{l}\text { funnel/ } \\
\text { blocky }\end{array}$ & $\begin{array}{c}\text { progadational/ } \\
\text { aggradational }\end{array}$ & SB & $\begin{array}{l}\text { low } \gamma(\text { API }), \\
\text { high } \rho(\Omega \mathrm{m})\end{array}$ \\
\hline & $\begin{array}{c}\text { sand/interbedded } \\
\text { shale }\end{array}$ & TST & bell & retrogradational & MFS & $\begin{array}{c}\text { high } \gamma \text { (API), } \\
\text { low } \rho(\Omega \mathrm{m})\end{array}$ \\
\hline & sand/shale & LST & $\begin{array}{l}\text { funnel and } \\
\text { blocky }\end{array}$ & $\begin{array}{c}\text { progadational/ } \\
\text { aggradational }\end{array}$ & TS & $\begin{array}{l}\text { deflection of } \gamma(\mathrm{API}) \\
\text { to the right }\end{array}$ \\
\hline \multirow{3}{*}{ S2 } & sand/shale & HST & $\begin{array}{l}\text { symmetrical } \\
\text { (bow) }\end{array}$ & $\begin{array}{c}\text { progadational/ } \\
\text { aggradational }\end{array}$ & SB & $\begin{array}{l}\text { low } \gamma(\mathrm{API}) \\
\text { high } \rho(\Omega \mathrm{m})\end{array}$ \\
\hline & sand/shale & TST & blocky & aggradational & MFS & $\begin{array}{c}\text { high } \gamma \text { (API), } \\
\text { low } \rho(\Omega \mathrm{m})\end{array}$ \\
\hline & sand & LST & funnel & progadational & TS & $\begin{array}{c}\text { deflection of } \gamma(\mathrm{API}) \\
\text { to the right }\end{array}$ \\
\hline \multirow{3}{*}{ S3 } & sand & HST & funnel & progadational & SB & $\begin{array}{l}\text { low } \gamma(\mathrm{API}) \\
\text { high } \rho(\Omega \mathrm{m})\end{array}$ \\
\hline & shale & TST & bell & retrogradational & MFS & $\begin{array}{l}\text { high } \gamma \text { (API), } \\
\text { low } \rho(\Omega \mathrm{m})\end{array}$ \\
\hline & sand/shale & LST & funnel & progadational & TS & $\begin{array}{c}\text { deflection of } \gamma(\mathrm{API}) \\
\text { to the right }\end{array}$ \\
\hline \multirow{3}{*}{ S4 } & sand & HST & blocky & aggradational & SB & $\begin{array}{l}\text { low } \gamma(\mathrm{API}) \\
\text { high } \rho(\Omega \mathrm{m})\end{array}$ \\
\hline & sand/shale & TST & bell & retrogradational & MFS & $\begin{array}{c}\text { high } \gamma \text { (API), } \\
\text { low } \rho(\Omega \mathrm{m})\end{array}$ \\
\hline & $\begin{array}{c}\text { sand/interbedded } \\
\text { shale }\end{array}$ & LST & blocky & aggradational & TS & $\begin{array}{c}\text { deflection of } \gamma(\mathrm{API}) \\
\text { to the right }\end{array}$ \\
\hline \multirow{3}{*}{ S5 } & $\begin{array}{c}\text { predominantly } \\
\text { sand with shale } \\
\text { laminae }\end{array}$ & HST & blocky & aggradational & SB & $\begin{array}{l}\text { low } \gamma(\mathrm{API}) \\
\text { high } \rho(\Omega \mathrm{m})\end{array}$ \\
\hline & $\begin{array}{l}\text { predominantly } \\
\text { shale }\end{array}$ & TST & bell & retrogradational & MFS & $\begin{array}{c}\text { high } \gamma(\mathrm{API}) \\
\text { low } \rho(\Omega \mathrm{m})\end{array}$ \\
\hline & sand & LST & blocky & aggradational & TS & $\begin{array}{c}\text { deflection of } \gamma(\mathrm{API}) \\
\text { to the right }\end{array}$ \\
\hline
\end{tabular}

Explanations: S - sequence, HST - high stand, TST - transgressive stand, LST - low stand, SB - sequence boundary, MFS - maximum flooding surface, TS - transgressive surface, $\gamma$ - gamma, $\rho$ - resistivity.

\section{Seismic sequence 1 (S1)}

The bulk of the S1 sequence consists of complex sigmoid/oblique clinoforms. The sequence is about $820 \mathrm{ft}$ thick as observed from the wells. This sequence commenced with a LST, which ranged from 3630 to $3200 \mathrm{ft}$ with an aggrading prograding fan characterized by a general trend of coarsening upward and a blocky signature comprising an intercalation of sand and shale. The MFS capped this system at depth of $3200 \mathrm{ft}$, and it is underlain by the transgressive surface at depth of $3200 \mathrm{ft}$. TST ranges from average depth of about 3190 to $3055 \mathrm{ft}$. It is bounded at the top by MFS1 and at the base by TS1, and characterized by fining upward log signature composed of retrograding shale and interbedded sand. The HST in the sequence extends from the MFS upward to depth $2810 \mathrm{ft}$. The HST is characterized by funnel and blocky shaped log motifs, and it composed of prograding sand.

\section{Seismic sequence 2 (S2)}

The sequence is estimated to be ca. $280 \mathrm{ft}$ thick. The S2 is dominated by complex sigmoid/oblique reflections. The sequence has a LST which extends from a depth $2800 \mathrm{ft}$ to TST, located at depth $2750 \mathrm{ft}$. LST is characterized by a coarsening 
upward log signature and it is generally comprised of prograding (fan) sand. The TST overlies the LST and extends from a depth of 2760 to $2630 \mathrm{ft}$ and dominated by the marine shale. MFS within this sequence occurs at a depth of $2630 \mathrm{ft}$ and it marks the base of the HST. The HST extends to a depth of $2520 \mathrm{ft}$. It is characterized by a bow-shaped log motif and is comprised of retrograding and prograding shale and sand sequence.

\section{Seismic sequence 3 (S3)}

Notable seismic facies within the sequence is the sigmoid/oblique reflection. The sequence beginning at a depth of $2510 \mathrm{ft}$ marks the onset of LST which is composed of prograding sand/shale intercalation as noticed from coarsening upward log signature. The LST terminates at a depth of $2451 \mathrm{ft}$ which marks the beginning of TST. The TST is characterized by fining upward log signature and dominated by retrograding marine (hemipelagic) shale. The HST lies above the TST and it is composed of fluvial sand characterized by a coarsening upward log signature. The MFS separates HST and TST at a depth of $2325 \mathrm{ft}$.

\section{Seismic sequence 4 (S4)}

The sequence comprises complex sigmoid-oblique and oblique (tangential) clinoform reflections, as well as subparallel to parallel reflections (Fig. 8). LST is characterized by a blocky log signature indicating the aggradation of sand and minor shale deposits. It extends from a depth of 2280 to $2175 \mathrm{ft}$. The TST overlies the LST and is characterized by a bell shape log signature indicating shale with minor sand deposit as a result of retrogradation. The HST is characterized by a blocky signature indicating aggradation of deltaic or fluvial sand bodies. The MFS which separates the HST and TST is located at a depth of $2120 \mathrm{ft}$.

\section{Seismic sequence 5 (S5)}

The S5 is characterized by reflections such as sigmoid, parallel, divergent, mounded, and hummocky clinoforms. The LST is characterized by a blocky signature indicating the aggradation of deltaic or fluvial sand into the marine. The TST is characterized by a bell-shape (fining upward) log signature, and its interpreted as being composed mainly of shale. It is at a depth between 1983 to 1920 $\mathrm{ft}$. The HST extends from the MFS5 to upper limit of the log. It is characterized by a blocky log signature composed mainly of sand with minor shales which occur as laminae within the blocky sand.

\section{Structural maps}

Depth structure maps were generated using the surface time-depth conversion algorithm in Petrel. Figure 11 shows the time-depth relationship plot used to generate the depth structure maps from the time structure maps.

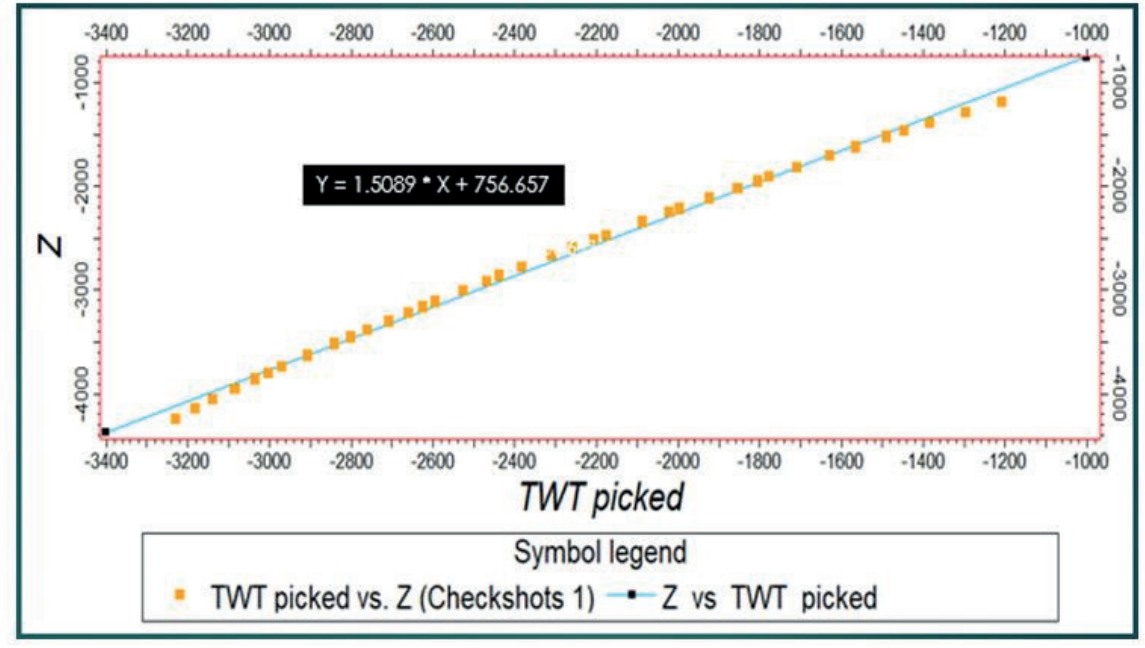

Scale 1:50000

Fig. 11. Time-depth conversion plot 

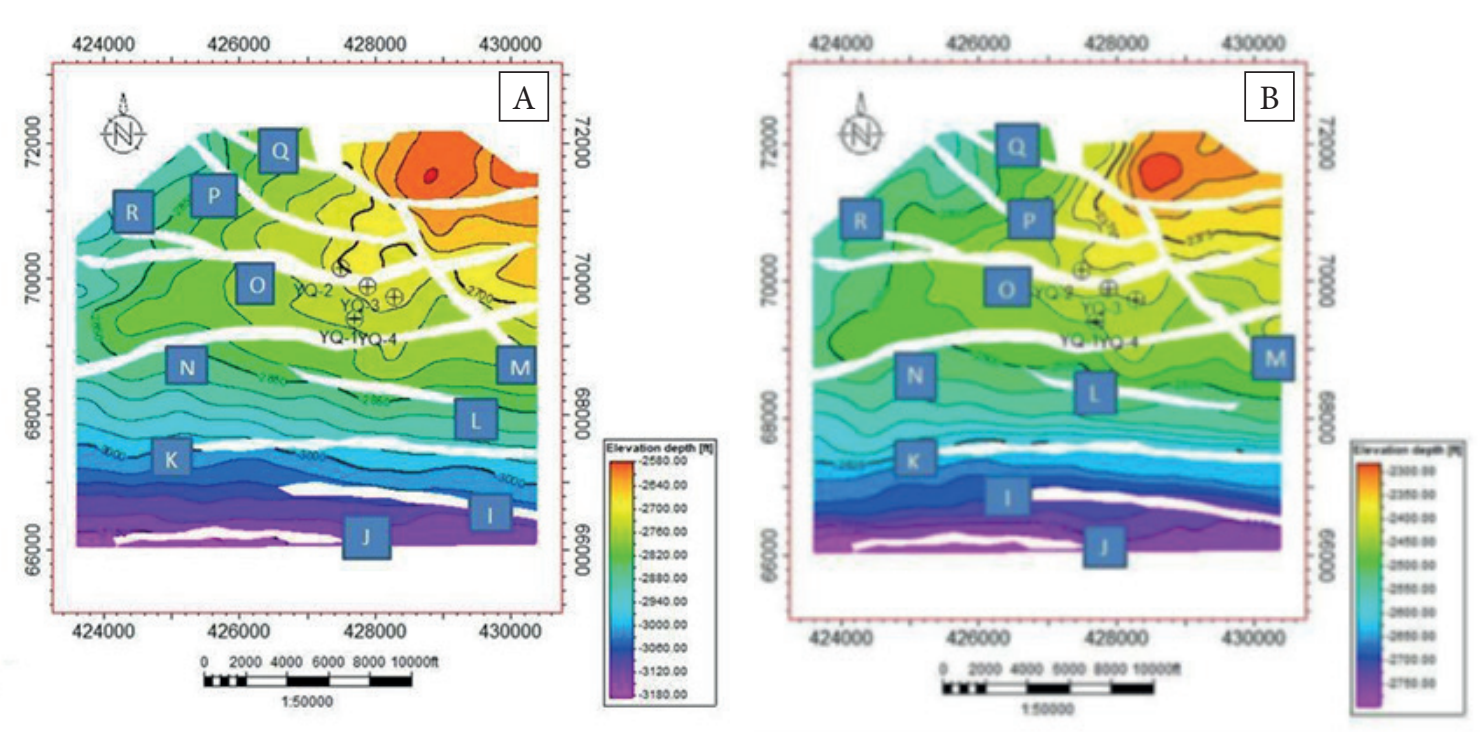

Fig. 12. Depth structure maps of MFS1 (A) and MFS2 (B)
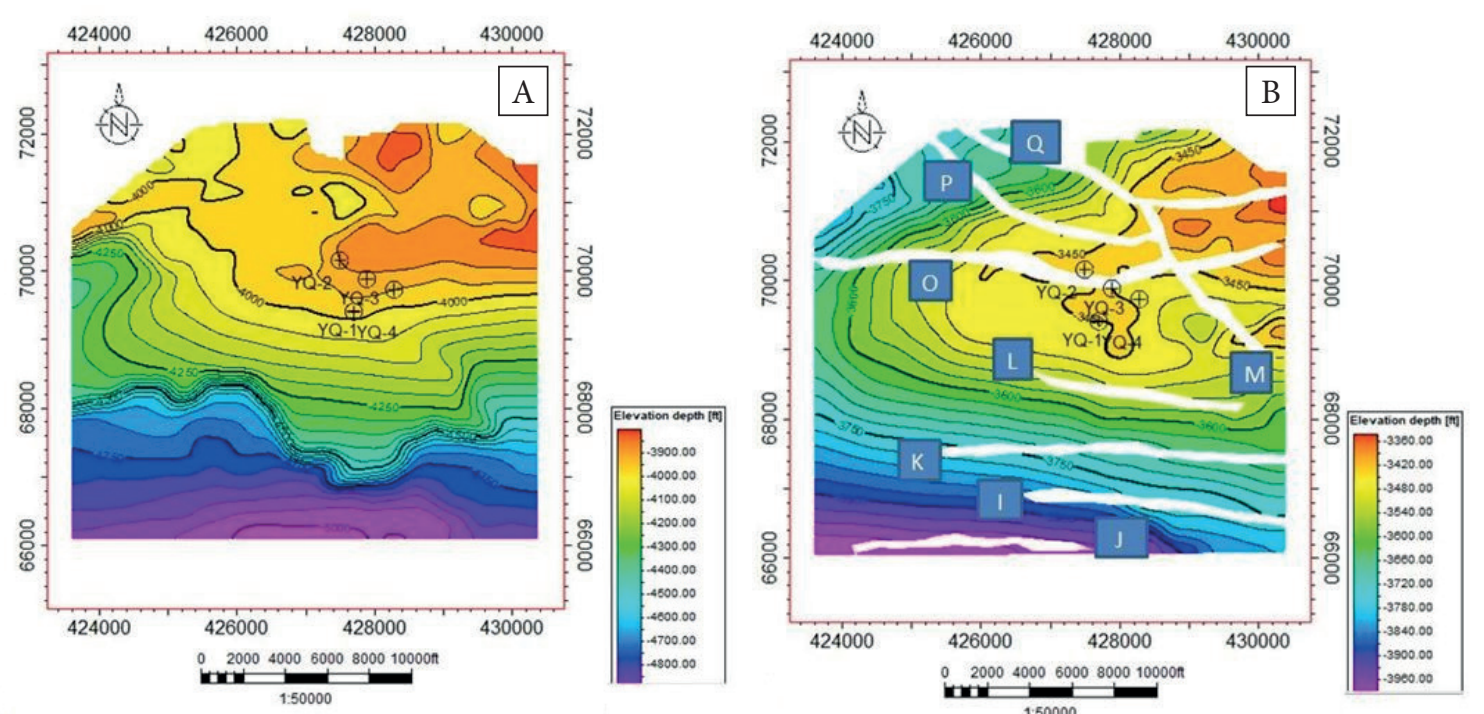

Fig. 15. Depth structure maps of SB1 (A) and $S B 2(B)$
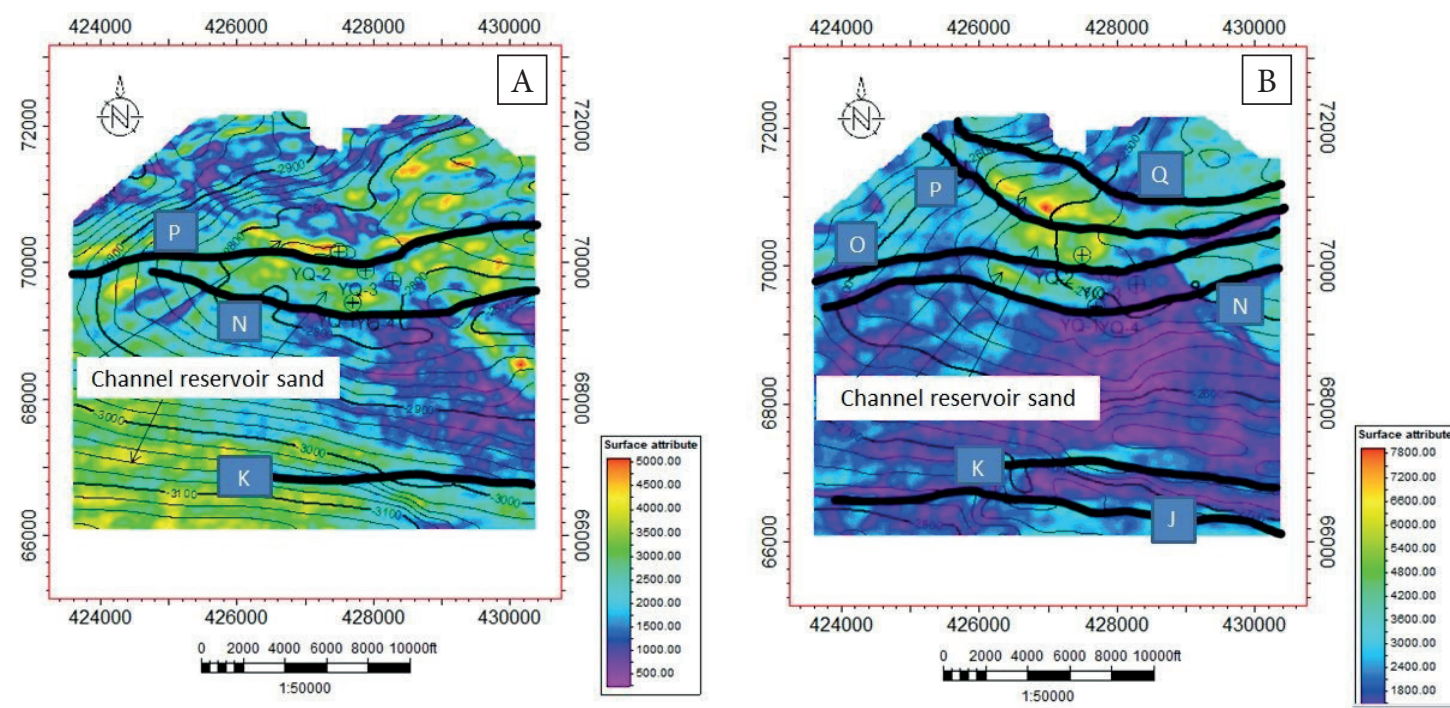

Fig. 18. RMS attributes extraction along SB2 (A) ond SB3 (B)
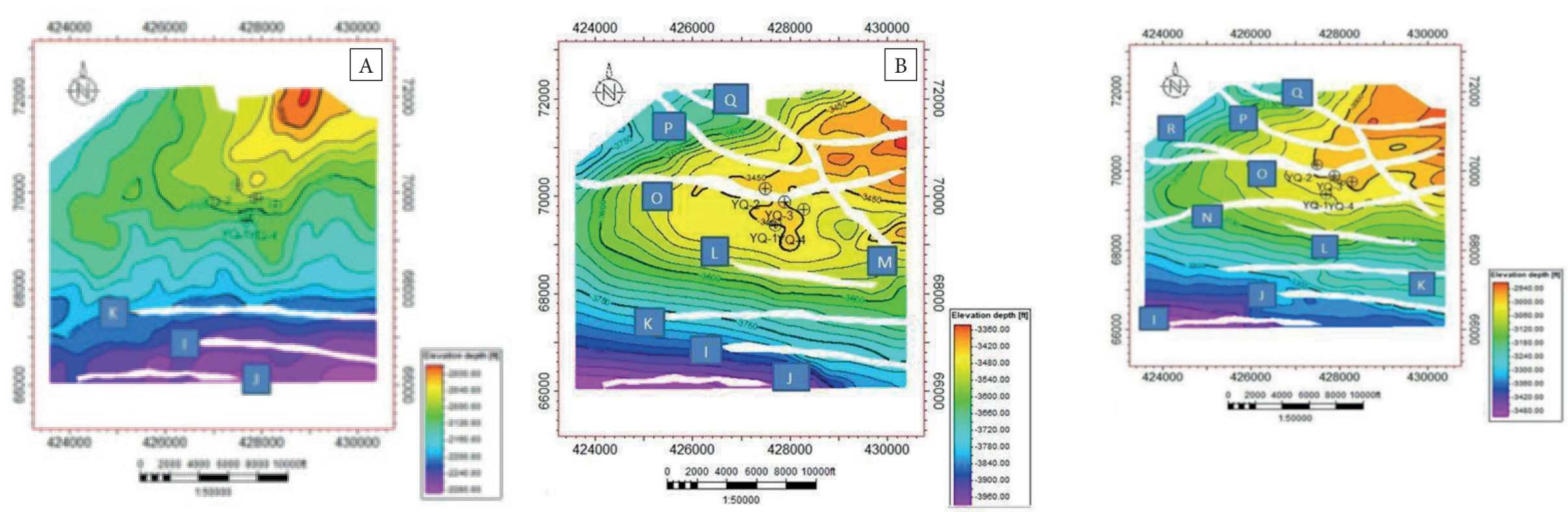

Fig. 13. Depth structure maps of MFS3 (A) and MFS4 (B)
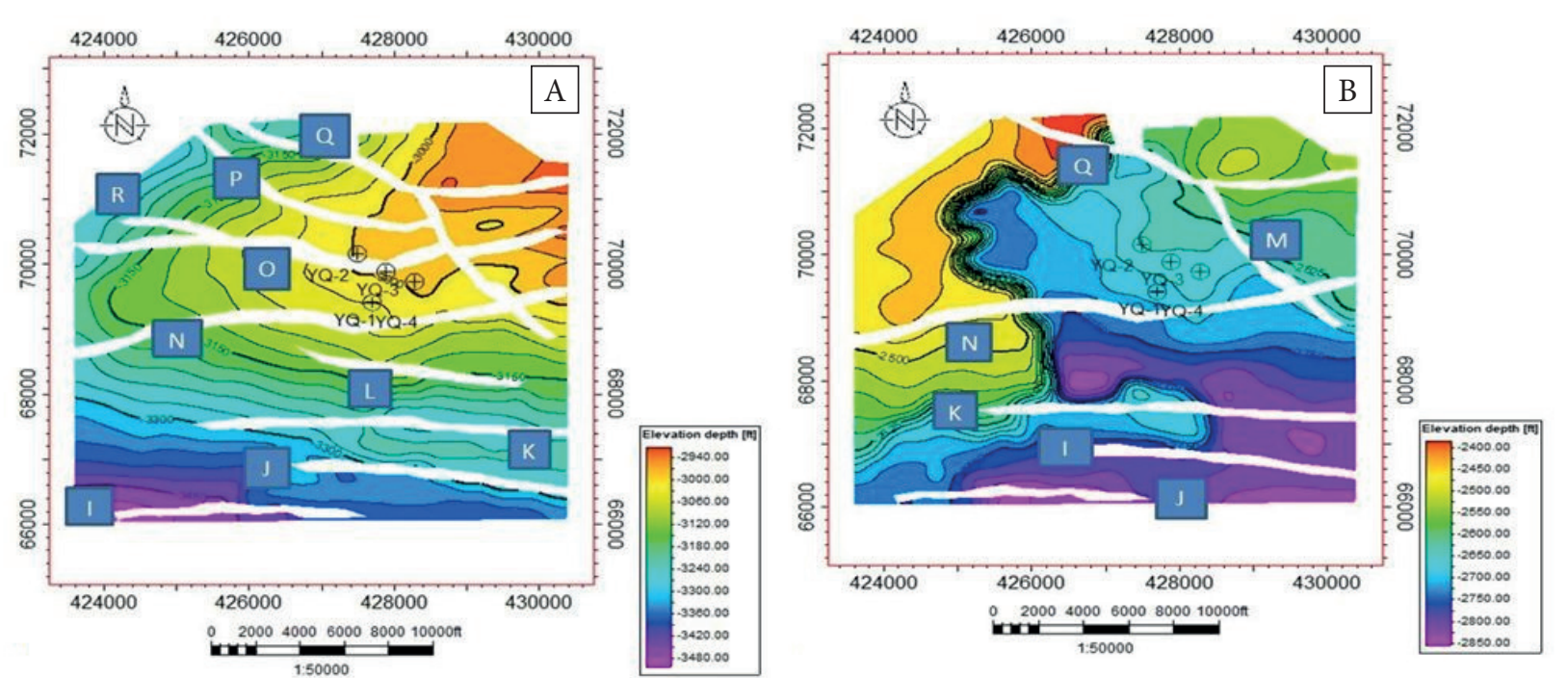

Fig. 16. Depth structure maps of SB3 (A) and SB4 (B)
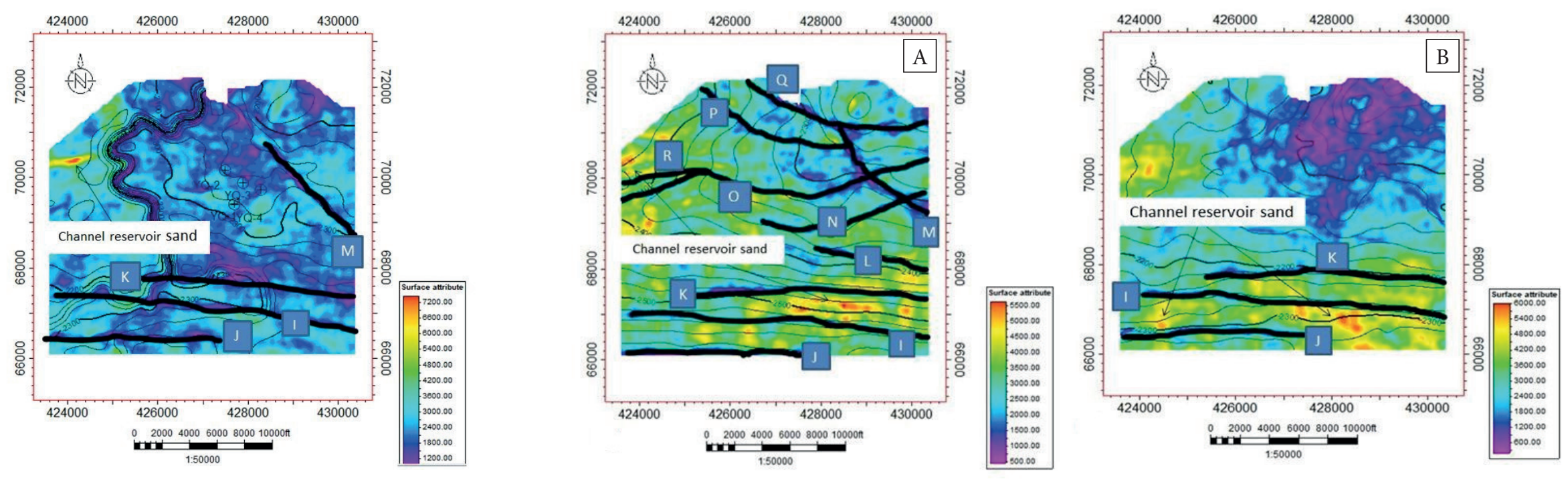

Fig. 20. RMS attributes extraction along MFS3 (A) and MFS4 (B)

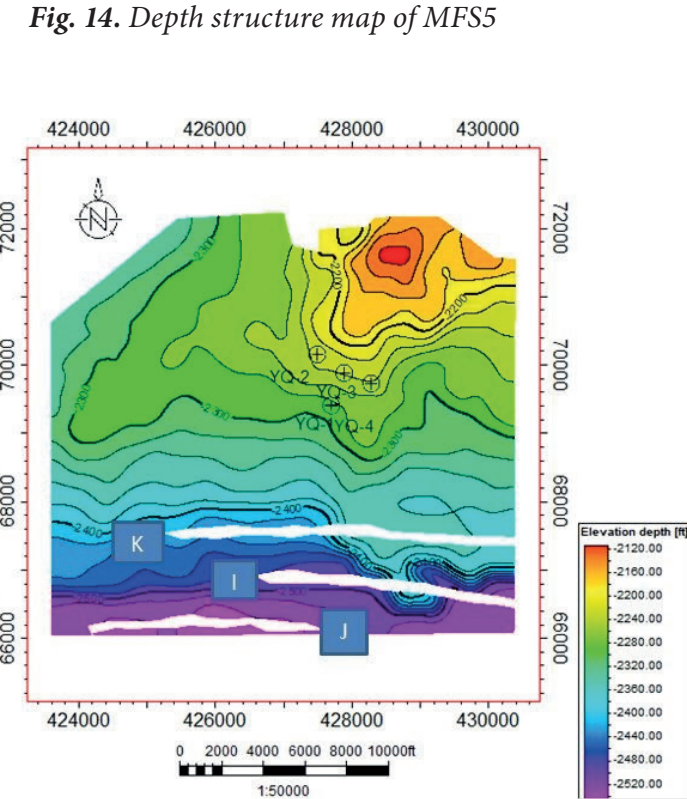

Fig. 17. Depth structure map of SBD 
The depth structure maps constructed for the MFS are shown in Figures 12-14. Generally, the southern parts are structurally low, whereas structurally high areas with associated possible closures are in the central and northeastern portions. Similar variations could be observed for the depth structure maps for the SB (Figs. 15-17) where structural highs and possible closure could be observed in the central and northeastern parts. The exception is in Figure 16B (structure map for SB4) where western to northwestern parts constitute the structural highs with no observable closure.

\section{Seismic attribute analysis}

Detailed information was obtained by extracting the amplitudes along selected surfaces within the
RMS attributed seismic volume. Figures 18 and 19 show examples of RMS attribute extractions draped on depth structure for the SB. Attributes along SB2 and SB3 indicate possible channel reservoir sand at the north-central portion. The channel sands are located within the earlier interpreted structural highs and possible closure from the depth structure maps (Figs. 12-14). On the contrary, possible channel sand is inferred in the western part on the depth structure map for SB4 (Fig. 19). Along MFS3 and MFS4, the channel reservoir sands are localized at the southwestern portion (Fig. 20). Associated reservoir sands that could be inferred on the well sections are shown in Figure 21.

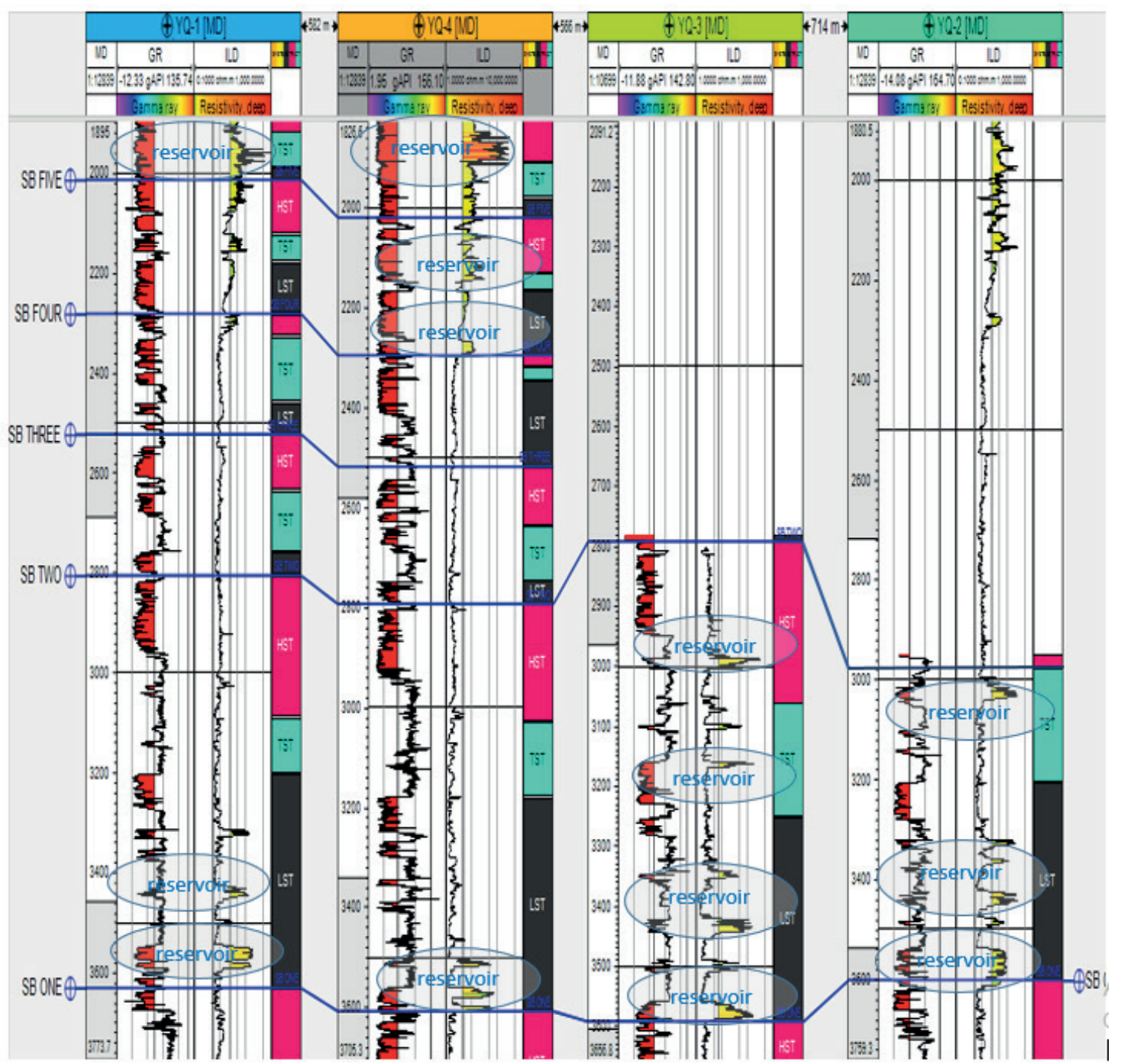

Fig. 21. Reservoir occurrence and associated system tracts in the Beta Field 


\section{DISCUSSION}

\section{Seismic sequence stratigraphy}

The preliminary evaluation of sequences and system tracts made by interpreting the lithofacies and correlated stratigraphic surfaces assisted in the determination of seismic sequences bounded above and below by seismic sequence boundaries. Based on the varying proportion of sand and shale observed in the four wells, the major lithostratigraphic units were interpreted to be within the Upper Agbada Formation. The Agbada Formation in the Niger Delta has been the target for drillings of reservoir rocks (Doust \& Omatsola 1990).

\section{Environment of deposition (EOD) interpretation}

The stacking patterns identified within the study area are: progradational, aggradational and retrogradational as observed from the log signatures (Fig. 21). From the interpretation of log trends and seismic facies, there is a progression from fluvial depositional environment to the shelf environment.

\section{Hydrocarbon play}

The sand units of the HST and LST within sequences 1,4 and 5 (S1, S4 and S5) are the main reservoirs identified within the field (Fig. 21). The interbedded sands within the TST of sequences 4 and 5 (S4 and S5) are also suspected to be potential reservoirs. The shale units of the TST within the sequences are suspected to be the main source of hydrocarbon trapped within the sequences in the Beta Field. The interbedded shale within S1 could also be a source of accumulated hydrocarbon in the sequence. The TST shales within the sequences might act as seal rocks that are essential for hydrocarbon accumulation and stratigraphic trapping.

\section{CONCLUSIONS}

The present study shows that the Beta Field is divisible into five depositional sequences, separated by unconformities and their correlative conformities. Identification of system tracts within the sequences based on bounding surfaces, position within sequence, and stacking patterns has facilitated identification of potential hydrocarbon plays in the studied field. Nine seismic facies were identified and interpreted. The depositional sequences and seismic facies were used to establish a progression of fluvial depositional settings to the shelf. The Upper Agbada Formation was the major lithostratigraphic units identified due to the dominating lithology of alternating sand and shale occurring approximately in a 65:35 ratios. The sand units of the HST and LST within S1, S4 and $\mathrm{S} 5$ are the main reservoirs identified within the field. The interbedded sands within the transgressive system tract of S4 and S5 are also suspected to be potential reservoirs. The integration of seismic stratigraphy in seismic interpretation can increase the chance of technical and economic success with regard to depositional and structural elements. Beta Field data interpretation has illustrated how improved interpretation of the subsurface can be achieved for a better understanding of uncertainties and reducing exploration risks. Detailed characterization for quantitative representation of identified reservoir sands may be done with data from other wells in the field. The integration of biostratigraphic data is required to determine the age of sequences and system tracts and to further establish the integrity of well correlations.

The authors are grateful to the University of Ibadan Geology Department, Schlumberger Company and the Department of Petroleum Resources of the Nigerian National Petroleum Corporation (NNPC) for the use of their research facilities. Colleagues and reviewers are also appreciated for comments that have helped to improve the quality of this article.

\section{REFERENCES}

Armentrout J.M. \& Perkin B.F. (eds.), 1991. Sequence Stratigraphy as an Exploration Tool: Concepts and Practices in the Gulf Coast. 11th Annual Research Conference, SEPM Society for Sedimentary Geology.

Brown L.F. \& Fisher W.L., 1977. Seismic stratigraphic interpretation of depositional systems: Examples from Brazilian rift and pull-apart basins. [in:] Payton Ch.E. (ed.), Seismic Stratigraphy: Applications to Hydrocarbon Exploration, AAPG Memoir, 26, American Association of Petroleum Geologists, Tulsa, 213-248. 
Catuneanu O., 2006. Principles of Sequence Stratigraphy. Elsevier, Amsterdam, Netherland.

Cawthra H.C., Frenzel P., Hahn A., Compton J.S., Gander L. \& Zabel M., 2020. Seismic stratigraphy of the inner to mid Agulhas bank, South Africa. Quaternary Science Reviews, 235, 105979.

Davies R.J., Cartwright J.A., Stewart S.A., Lappin M. \& Underhill J.R. (eds.), 2004. 3D Seismic Technology: Application to the Exploration of Sedimentary Basins. Geological Society Memoir, 29, Geological Society of London.

Cross T.A. \& Lessenger M.A., 1988. Seismic Stratigraphy. Annual Review of Earth Planetary Sciences, 16, 319-354.

Doust H., 1990. Petroleum Geology of the Niger Delta. [in:] Brooks J. (ed.), Classic Petroleum Provinces, Geological Society Special Publication, 50, Geological Society of London, 365

Doust H. \& Omatsola E., 1990. Niger Delta. [in:] Edwards J.D. \& Santogrossi P.A. (eds.), Divergent/Passive Margin Basins, AAPG Memoir, 48, American Association of Petroleum Geologists, Tulsa, 239-248.

Ejedawe J.E., 1981. Patterns of incidence of oil reserves in $\mathrm{Ni}$ ger Delta Basin. American Association of Petroleum Geologists Bulletin, 65, 1574-1585.

Ejedawe J.E., Coker S.J.L., Lambert-Aikhionbare D.O., Alofe K.B. \& Adoh F.O., 1984. Evolution of oil-generative window and oil and gas occurrence in Tertiary $\mathrm{Ni}$ ger Delta Basin. American Association of Petroleum Geologists Bulletin, 68, 1744-1751.

Ekweozor C.M. \& Daukoru E.M., 1984. Petroleum source bed evaluation of Tertiary Niger Delta - reply. American Association of Petroleum Geologists Bulletin, 68, 390-394.

Ekweozor C.M. \& Daukoru E.M., 1994. Northern delta depobelt portion of the Akata-Agbada(!) petroleum system, Niger Delta, Nigeria. [in:] Magoon L.B. \& Dow W.G. (eds.), The Petroleum System - From Source to Trap, AAPG Memoir, 60, American Association of Petroleum Geologists, Tulsa, 599-614.

Ekweozor C.M., Okogun J.I., Ekong D.E.U. \& Maxwell J.R., 1979. Preliminary organic geochemical studies of samples from the Niger Delta, Nigeria: Part 1, analysis of crude oils for triterpanes. Chemical Geology, 27, 11-28.

Galloway W.E., 1975. Process framework for describing the morphologic and stratigraphic evolution of deltaic depositional systems. [in:] Broussard M.L. (ed.), Deltas: Models for Exploration, Houston Geological Society, 87-98.

Galloway W.E., 1976. Sediments and stratigraphic framework of the Copper River fan-delta, Alaska. Journal of Sedimetary Petrology, 46, 726-737.

Galloway W.E., 1998. Siliciclastic slope and base of slope depositional systems: Component facies, stratigraphic architecture, and classification. American Association of Petroleum Geologists Bulletin, 82, 569-595.
Galloway W.E. \& Hobday D.K., 1983. Terrigenous Clastic Depositional Systems. Springer Verlag, New York.

Miall A.D., 1991. Stratigraphic sequences and their chronostratigraphic correlation. Journal of Sedimentary Petrology, 61, 497-505.

Mitchum R.M., Jr., Vail P.R. \& Sangree J.B., 1977. Seismic stratigraphy and global change of sea level, Part 6: Stratigraphic interpretation of seismic reflection patterns in depositional sequences. [in:] Payton Ch.E. (ed.), Seismic Stratigraphy: Applications to Hydrocarbon Exploration, AAPG Memoir, 26, American Association of Petroleum Geologists, Tulsa, 117-133.

Murat R.C., 1972. Stratigraphy and paleogeography of the Cretaceous and Lower Tertiary in Southern Nigeria. [in:] Dessauvigie T.F.J. \& Whiteman A.J. (eds.), African Geology, University of Ibadan Press, Ibadan, 635-648.

Payton Ch.E., 1977. Seismic Stratigraphy: Application to Hydrocarbon Exploration. AAPG Memoir, 26, American Association of Petroleum Geologists, Tulsa.

Paumard V., Bourget J., Durot B., Lacaze S., Payenberg T., George A.D. \& Lang S., 2019. Full-volume 3D seismic interpretation methods: A new step towards high-resolution seismic stratigraphy. Interpretation, 7(2), B33-B47.

Posamentier H.W. \& George P.A., 1994. Siliciclastic Sequence Stratigraphy: Concepts and Application. AAPG Short Course, 10, SEPM Society for Sedimentary Geology.

Ramsayer G.R., 1979. Seismic stratigraphy, a fundamental exploration tool. [in:] Offshore Technology Conference, 30 April-3 May, Houston, Texas, 101-109.

Slatt R.M., 2013. Deepwater deposits and reservoirs. Development in Geosciences, 61, 475-552.

Snedden J.W. \& Sarg J.F., 2008. Seismic Stratigraphy A Primer on Methodology. AAPG Search and Discovery Article, American Association of Petroleum Geologists, Tulsa.

Van Wagoner J.C., Posamentier H.W., Mitchum R.M., Vail P.R., Sarg J.F., Loutit T.S. \& Hardenbol J., 1988. An overview of the fundamentals of sequence stratigraphy and key Definitions. [in:] Wilgus C.K., Hastings B.S., Ross C.A., Posamentier H., Van Wagoner J.C., Kendall C.G.St.C. (eds.), Sea-Level Changes: An Integrated Approach, Society of Economic Paleontologists and Mineralogists Special Publication, 42, Society of Economic Paleontologists and Mineralogists, 39-45.

Van Wagoner J.C., Mitchum R.M., Campion K.M. \& Rahmanian V.D., 1990. Siliciclastic Sequence Stratigraphy in Well Logs, Cores, and Outcrops. AAPG Methods in Exploration Series, 7, American Association Petroleum Geologists, Tulsa.

Veeken P.C.H., 2007. Seismic Stratigraphy, Basin Analysis and Reservoir Characterization. Handbook of Geophysical Exploration: Seismic Exploration, 37, Elsevier. 